\title{
Jean-Martin Charcot's Contributions to the Interface Between Neurology and Psychiatry
}

\author{
Michel B.White
}

\begin{abstract}
Although much has been written about Jean-Martin Charcot (1825-1893) as a neurologist and his commitment to the hysterics of the Salpêtrière, his influence on modern psychiatric thought has been misunderstood. His contributions range from the diagnosis and understanding of certain aspects of hysteria, which influenced psychoanalysis, to insights into the psychopathology of trauma that foreshadow modern concepts of post-traumatic stress disorder and somatoform disorders. This article reviews these aspects in the context of his contributions as a founder of modern neurology, neuropathology and proponent of the anatomo-clinical approach.
\end{abstract}

RÉSUMÉ: Les contributions de Jean-Martin Charcot à l'interface entre la neurologie et la psychiatrie. Il existe une abondante littérature ayant trait aux contributions de Jean-Martin Charcot (1825-1893) en tant que neurologue et son implication auprès des hystériques de la Salpêtrière. Cependant, son influence sur la pensée psychiatrique moderne reste méconnue. Ses contributions portent tant sur le diagnostic et la compréhension de certaines facettes de l'hystérie, qui sont à l'origine de la psychanalyse, que sur la psychopathologie du traumatisme. Elles laissaient déjà entrevoir certaines conceptions modernes sur l'état de stress post-traumatique et les troubles somatoformes. Cet article étudie ces notions dans le contexte des contributions de Charcot en tant que fondateur de la neurologie moderne, de la neuropathologie et promoteur de la méthode anatomo-clinique.

Can. J. Neurol. Sci. 1997; 24: 254-260

Jean-Martin Charcot's prodigious output and insights are more than ever relevant in our "decade of the brain" where neurology, neuropsychiatry and psychiatry continue to discover new grounds for exchange. Neuropsychiatry deals with the neurobiological components, assessment and optimal treatment of behavioral disorders associated with illnesses of the nervous system. It also studies the neurobiology of psychiatric disorders. ${ }^{1}$ Although it has a very long history in Europe, it is now enjoying a worldwide renaissance. With limited means and essentially an organicist working independently from the alienists (psychiatrists) of his time, Charcot contributed to this interface more than a century ago through his application of the anatomo-clinical method to various neurological diseases and subsequently to hysteria. Unfortunately, his historical attempt to apply the method to the hysterics of the Salpêtrière was not successful. This unjustly discredited much of his insights, and the subsequent influence of psychoanalysis on psychiatric thought contributed further to separate neurology and psychiatry.

In 1982, an exhibition on Charcot's work with hysteria was held at the Salpêtrière and was the starting point of much subsequent scholarship. More recently, to commemorate Charcot's centenary, some conferences have been published in the Revue Neurologique. ${ }^{2}$ A recent contribution by Jacques Gasser ${ }^{3}$ and a definitive biography by Goetz, Bonduelle and Gelfand ${ }^{4}$ in 1995 have greatly added to our understanding of Charcot's life and his contributions as a creator of modern neurology. Exciting scholarship by Gilman, King, Porter, Rousseau and Showalter, ${ }^{5}$ along with works by Shorter, ${ }^{6,7}$ have widened our understanding of the socio-historical aspects of hysteria. However, Micale, ${ }^{8}$ in his attempt to articulate a non-dogmatic sociosomatic model of hysteria, deplored the lack of retrospective rediagnosis of Charcot's patients and called for more interdisciplinary inquiry between scientists and humanists.

This article explores certain parallels between Charcot's thinking and later diagnoses such as conversion disorder. Furthermore, his notions concerning the neurological impact of trauma antedate some of our current ideas behind the biological aspects of post-traumatic stress disorder (PTSD) and psychosomatic medicine. Therefore, his perspective seems particularly interesting in retrospect as we now witness the renaissance of neuropsychiatry and evidence of biological correlates for many psychiatric entities.

\section{The Salpêtrière and the anatomo-clinical method}

Charcot took charge of the Salpêtrière medical service in 1862. This hospital already had an illustrious past. Used as an

From the Behavioral Neurology Unit, Neurology Service, Hôtel-Dieu de Montréal Hospital, Montréal.

RECEIVED APRIL 24, 1996. ACCEPTED IN FINAL FORM FEBRUARY 27, 1997.

Reprint requests to: Michel B. White, M.D., Department of Neurology, Hôpital HôtelDieu de Montréal, 3840 St-Urbain, Montréal, Québec, Canada H2W 1T8 
arsenal during the 13th century, it was transformed during the 17 th century into a women's hospice. It then housed criminals, the mentally retarded, maniacs and neurosyphylitics who lived in abysmal conditions. In 1795, the famous psychiatrist Philippe Pinel, who had taken charge of the hospice a year earlier, participated in the liberation of the insane. Upon his arrival, Charcot described the Salpêtrière as a "... large asylum with a population of about 5000 people, including a large number of incurables and women of all ages with every kind of chronic disease, particularly those of the nervous system ... in other words, we are in possession of a kind of living pathological museum of considerable resources". 9,10

Under Charcot's supervision, older buildings were transformed into a research center for diseases of the nervous system. It is here that he brought the anatomo-clinical method to its most brilliant and elegant expression. This approach, which is the basis of Charcot's scientific orientation and work, is an attempt to identify and understand illnesses by correlating signs and symptoms with a postmortem search for organic lesions. Although known before Charcot and rooted in ideologies such as Experimentalism, Determinism and Positivism, the anatomoclinical method was applied for the first time by Charcot to the systematic study of the nervous system and represents his scientific legacy. ${ }^{11}$ It highlights his genius at approaching and understanding polymorphous entities such as Graves-Basedow's disease, hereditary amyloidosis (Charcot-Marie's disease), multiple sclerosis (which he discovered) and amyotrophic lateral sclerosis, among others. Before his neuropathological work, which he carried out from 1870 to 1878 , Charcot had already published papers on intermittent claudication, ${ }^{12}$ diabetic gangrene ${ }^{13}$ and geriatrics. ${ }^{14}$ The anatomo-clinical method eventually led to his greatest success, the localization of cortical motor functions in 1875.15 .16

Charcot also studied les trembleuses de la Salpêtrière (tremor in female patients). His work with Vulpian led to the distinction between resting tremor associated with paralysis agitans (Parkinson's disease) and intention tremor seen in multiple sclerosis. ${ }^{17,18}$ However, it is his contributions to the creation of clinical neurology which were recognized internationally and culminated in his appointment to the first Chair of Clinical Nervous Diseases in 1882.

\section{Charcot and the alienists of his time}

There has been much controversy concerning Charcot's contributions to the psychiatry of his time. Hysteria, which had been considered a mental illness and therefore under the alienists' jurisdiction, was redefined by Charcot as belonging to neurology. ${ }^{4}$ This later led to heated public debates between psychiatrist Gilbert Ballet ${ }^{19}$ and neurologist Joseph Dejerine. ${ }^{20}$ As outlined by Goetz et al., ${ }^{4}$ this debate in itself pointed to the fact that both Parisian psychiatrists and neurologists saw Charcot as their common progenitor and openly credited him for introducing a psychological contribution to the genesis of hysteria. However, Charcot worked separately from the alienists, and although he did see psychiatric patients in his outpatient clinic, they occupied a small proportion of his practice. ${ }^{21}$ During the second half of the 19th century, French psychiatrists tended to view mental illness as hereditary in origin and elaborated the concept of degeneration. German psychiatrists, such as Wilhelm Griesinger and Theodor Meynert, were more involved with the possible neuroanatomical etiology of psychiatric disorders. These schools can be seen as the ancestors of modern biological psychiatry.

\section{Charcot as behavioral neurologist}

Soon after his arrival at the Salpêtrière Hospice, Charcot began writing, along with Charles Bouchard, his first papers on aphasia. ${ }^{22.23}$ Although their importance was acknowledged by Pierre Janet ${ }^{24}$ and recently by F. Lhermitte and J.L. Signoret, ${ }^{25}$ this work has been mostly ignored by his biographers. Charcot defined psychology as the physiological operations of certain brain regions. ${ }^{4}$ Much of his thought on the subject was inspired by Théodule Ribot's 1881 monograph "Les maladies de la mémoire". ${ }^{26}$ Ribot's modular approach to language taught that language is a multi-faceted faculty. Charcot, by integrating clinical, psychological and neuropathological data, was one of the first to attempt a unification of the psychological and physiological aspects of language, a concept that was popularly known at that time as la psychologie physiologique. Through various aspects of aphasia, Charcot studied the auditory, visual, phonetic and motor elements of language and correlated them with different brain locations. He had previously described 4 cases of "aphemia", and Paul Broca later incorporated Charcot's findings into his evidence of left frontal lobe lesions implicated in speech deficits. ${ }^{4,27}$ He further introduced the works of "diagram makers" to the French scientific community. In 1885, with Ribot and Paul Janet, Charcot created the Société de Psychologie Physiologique. Although short-lived, this society further reflected his desire to integrate aspects of psychology and pathology. ${ }^{15}$ His interest in aphasia culminated in a series of 14 lectures given at the Salpêtrière in 1883 and 1884 .

As expressed well by Brais, ${ }^{28}$ although the principles of $l a$ psychologie physiologique had been elaborated since 1873 by Wundt, ${ }^{29}$ Charcot's efforts were to distinguish this new area from classical introspective and experimental types of psychology by emphasizing clinical and pathological data and refraining from animal experimentation. Although he has received little recognition for these efforts, Charcot's contributions should be viewed, at least conceptually, as precursors of modern behavioral neurology.

\section{The hysterics of the Salpêtrière: hysteria and hypnosis find a new stage}

The study of hysteria occupied the second part of Charcot's career. He was first confronted with hysteria as a consequence of administrative reforms within the Salpêtrière in 1870 , when female patients with "episodic behavior" such as epileptics and hysterics were rehoused in the same building, "le quartier des épileptiques simples". ${ }^{30}$

To understand Charcot's contributions to the study of hysteria, it must be remembered that, at the end of the 18 th century, there already existed 4 main etiological explanations of hysterical manifestations. One organic approach, which had a long history, conceptualized hysteria as having a uterine origin. Indeed, Hippocrates first introduced the word hystera in his Corpus Hippocraticum. This concept was derived from the Egyptian theory of the wandering uterus. ${ }^{30}$ During the Renaissance, thanks to the medical contributions of Paracelsus (1493-1541), Vesalius (1514-1564) and Paré (1517-1590?), the wandering uterus resurfaced in a hybrid form through the notion of toxic 
uterine secretions. The uterine theory was abandoned after the publication of Paul Briquet's (1798-1881) masterful Traité clinique et thérapeutique de l'hystérie, published in $1859,{ }^{31}$ which ascribed hysteria to higher centers, calling it une névrose de l'encéphale (encephalic neurosis). This second point of view was in line with earlier writings by Thomas Sydenham in England, who simply considered hysteria as belonging to les passions de l'ame (passions of the soul).$^{30}$ However, during the mid-19th century and especially through the medical works of authors such as Négrier, ${ }^{32}$ a third point of view presented hysteria as the result of ovarian congestion. Finally, another organic etiology considered hysteria to be a disease of the nervous system. This concept had initially been evoked during the 17 th century by Charles LePois (1563-1633) in France and later by Thomas Willis (1622-1675) in England.

The last quarter of the 19th century witnessed a rethinking of notions concerning masculinity and feminity. Charcot's work reflected this shift. ${ }^{33,34}$ Although male hysteria had been described as early as the second century AD by the Roman anatomist Galien de Pergame (129-199), ${ }^{30}$ and later by Sydenham who called it hypochondriasis, Charcot was among the first, along with Briquet, to describe male hysteria in detail and apply scientific enquiry to its multi-faceted presentations.

In trying to understand Charcot's approach to hysteria, one must keep in mind that there is no unified Charcotian theory of hysteria, but rather an evolving reflection over a period of 2 decades. ${ }^{35}$ Charcot's first approach to hysteria was to apply the anatomo-clinical method, whose successes had brought him world-wide recognition, and try to create a recognizable nosological entity. His studies centered mainly around "hysteroepilepsia", a term coined earlier by Briquet who considered it a mixture of epilepsy and hysteria. However, for Charcot, hysteroepilepsy was a pure form of hysteria. He initially described a complete grande attaque hystérique (hysteria major) in 4 distinctive stages, later adding many formes frustres (incomplete versions), and hysterical stigmata such as "hysterogenic zones" and other manifestations such as hemi-anesthesia and ovarian hyperesthesia. For the study of hysteria, as he had done for his studies of the nervous system, Charcot made abundant use of his photography studio and the exceptional drawing talents of his intern, Paul Richer, a professor of artistic anatomy at $l$ 'Ecole Nationale des Beaux-Arts.

Charcot's psychological explanation for the production of hysterical symptoms was that a patient forgot a particular bodily function. As emphasized by Widlocher, ${ }^{36}$ this point of view was in accordance with the psychological theories of Ribot and Spencer which considered that the idea of a movement preceded the movement itself. In the case of hysterical paraplegia, for example, the patient replaces the idea of movement with the idea of the impossibility of movement. Hypnosis therefore played a very important role in the diagnosis of this false idea. Although he could not find any, Charcot believed in lesions of the nervous system which could account for the wide array of hysterical symptoms and would eventually yield to pathological scrutiny. ${ }^{37}$ As explained well by Goetz et al., ${ }^{4}$ Charcot used the paradox of a "dynamic lesion" to indicate "a reversible or imperceptible alteration of tissues, perhaps a metabolic or chemical change". Nonetheless, the possibility of duplicating or removing a symptom through hypnotic procedures, which he called suggestion traumatique (traumatic suggestion), became a diagnostic tool for hysteria. Indeed, he believed that the hypnotic state was a physiological process characteristic of hysteria. This was crystallized by his statement "what one has done, one can undo, in the matter of suggestion". 38

However, and this was the School of Nancy's criticism of Charcot's work with hysteria, he never fully realized the therapeutic possibilities of hypnosis. Hippolyte Bernheim (18371919), who was President of the Nancy Medical Society, considered that la grande attaque was a product of training and modelling, a névrose hypnotique collective (collective hypnotic neurosis). The power of shared beliefs and expectations between client and therapist, or "demand characteristics", was certainly underestimated by the Parisian school. ${ }^{39,40}$ Furthermore, Charcot was probably unaware of the powerful influence of suggestion when epileptics and hysterics were grouped in "le quartier des épileptiques simples". However, hystero-epilepsy was witnessed outside of the Salpêtrière, but rarely with the florid features that Charcot described. In England, William Gowers (1845-1915), who did much to differentiate true epilepsy from its hysterical presentation, noted that, in England, hystero-epilepsy did not reach the same intensity as it did at the Salpêtrière and that the ovarian compression test was seldom successful. 11,42

Charcot's original contributions to the understanding of hysteria were further discredited through Babinski's concept of pithiatism, which proposed that certain disorders of the central nervous system were simply brought about and cured by suggestion. ${ }^{4,43}$ As pointed out by Merskey, ${ }^{44}$ Babinski's definition was subsequently rejected by Dejerine, Raymond, Janet, Pitres and others, as many hysterical manifestations were not the result of suggestion. Furthermore, the role of emotion in the genesis of hysteria was grossly underestimated by Babinski. Although Charcot (and his collaborators) unwittingly contributed to the production of specific symptom clusters such as la grande attaque and "hysterogenic zones" (in this sense, Babinski's objections were valid), he was also confronted with other clinical syndromes that were not his creation, were different from la grande attaque and resembled the modern-day diagnosis of conversion disorder and certain aspects of PTSD. In fact, it has been estimated that as little as $12 \%$ of patients diagnosed as hysterical at the Salpêtrière between 1870 and 1910 displayed $l a$ grande attaque. ${ }^{8}$ Most were minor forms of hysteria. Interestingly, some French authors and British neurologists have recently reported la grande attaque and formes frustres as described by Charcot and Richer. ${ }^{45,46}$

\section{Charcot and multimodal approaches to hysteria}

Charcot's approach to the diagnosis and treatment of hysteria foreshadowed modern multimodal approaches to conversion disorder. His use of hypnosis for diagnostic purposes is still valid today. ${ }^{47}$ Contrary to common belief, Charcot did occasionally use it as a treatment. ${ }^{48}$ Leon Chertok ${ }^{49}$ even considers that Charcot's report on hypnotism in $1882,{ }^{50}$ before the Academy of Sciences, opened a new era in psychotherapy.

Charcot's treatment of hysterical symptoms was dual. A first modality known as psychical (or moral) treatment, which Charcot believed was essential, stressed the value of isolating the patient from the environment where symptoms originated. Although isolation was first used by the American physician Silas Weir Mitchell (1829-1914), Charcot had also noticed that environmental factors often contributed to maintaining 
symptoms. This is very much in line with modern behavioral ${ }^{51}$ and interpersonal ${ }^{52-54}$ concepts of conversion disorder. For example, in his treatment of 3 children suffering from psychogenic seizures, ${ }^{55}$ Charcot used behavioral elements, permitting the family to visit the patient, "à titre de récompense" (as a reward), as improvement was noted. In this particular example, the second modality called medical treatment, involved electro and hydrotherapies. For other patients who suffered from functional paralysis, active encouragement in conjunction with physiotherapeutic interventions such as massages, passive and active movements of the limbs were recommended.

Multimodal approaches with a strong element of suggestion or hypnosis have been shown to be useful in the treatment of conversion disorder. ${ }^{56-60}$ Some of these approaches have stressed the importance of physiotherapy and behavioral modification, ${ }^{57}$ which tend to be favored over hypnosis by British neurologists. ${ }^{56}$ Sodium amytal interviews, which have recently been reemphasized in the literature, are sometimes added for treatment and diagnostic purposes. ${ }^{47,59,61,62}$

\section{Hysteria: classification and neurological issues}

The year 1995 represents the centenary of the first publication of Joseph Breuer and Sigmund Freud's Studies in Hysteria.$^{63}$ Although the diagnosis of hysteria has not been retained since the American Psychiatric Association's DSM-III classification, hysteria remains one of the oldest and most polymorphous entities in the history of psychiatry. An appropriate metaphor would be that hysteria, confronted with the stressors of contemporary efforts to classify mental illness, suffered its own grande attaque and therefore split into multiple nosological entities such as conversion disorder, Briquet's syndrome (the more recent concept of somatization disorder represents its diluted form) and dissociative disorders. Many patients described by Charcot would probably fit the modern DSM-IV diagnoses of conversion disorder, somatization disorder, posttraumatic stress disorder, factitious disorder and, in a limited number of cases, malingering. ${ }^{64}$

However, although better classified, hysteria continues to elude clinicians, especially in the form of conversion disorder. Conversion reactions display shifting illness presentation which is culturally-bound $\mathrm{d}^{6,7.65}$ and its annual incidence in psychiatric practice has been estimated to be as low as $0.01-0.02 \%{ }^{66}$ Conversely, hysterical symptoms account for $1-9 \%$ of diagnoses in neurological practice. ${ }^{67,68}$ Unfortunately, conversion disorder continues to thrive in a grey zone between neurology and psychiatry, at least in its management. Indeed, many patients do not want to acknowledge the psychological origin of their symptoms and therefore develop a fluctuating and sometimes chronic course. Brisset's statement ${ }^{69}$ that "Mesmer was attracting hysterics, Charcot was cultivating them, Babinski repressed them and we continue the repression" is still somewhat relevant today.

In terms of diagnosis, it has been suggested that Charcot mistook many organic syndromes for hysteria, a good example being epilepsy itself. Some patients with closed head injury may have been misdiagnosed as suffering from hysterical seizures. Before the advent of the neuron theory in 1891, on the basis of normal electrical reactions to stimulation and the absence of muscle wasting, Charcot also probably confused some upper motor neuron lesions with hysteria ${ }^{70}$ The misdiagnosis of a truly organic pathology still holds true today, as approximately
$25 \%$ of patients receiving a diagnosis of conversion disorder later develop organic disorders which can account for their initial symptoms. ${ }^{71}$

The above notwithstanding, recent research has in fact pointed towards a possible neuropsychology of conversion disorder. The concept of cerebral dysfunction has been postulated, implicating non-dominant hemispheric vulnerability. This association with the right hemisphere is partially supported by the lifetime prevalence of major depressive disorder in $18 \%$ of welldelineated conversion disorders ${ }^{72}$ and the higher left-sided frequency of conversion symptoms ${ }^{73,74}$ especially in women ${ }^{75}$ In view of Charcot's concepts of a "forgotten bodily function" and dynamic lesions, it has also been recently suggested that excessive cortical arousal and increased levels of cortical tone may alter subjective bodily awareness and explain anomalous sensory perception in conversion disorder. ${ }^{66,76,77}$ Flor-Henry et al. ${ }^{78}$ have described, in preliminary brain-imaging studies, impaired inter-hemispheric communication with hypermetabolism of the non-dominant hemisphere and hypometabolism of the dominant hemisphere, which remind us of Charcot's concept of dynamic lesions. Although these studies point toward an emerging "physiology" of conversion disorder, this area needs to be clarified through more research.

\section{Traumatic hysteria: foundations, influence and modern bio-} logical correlates

Charcot's major and most interesting contribution at the interface between neurology and psychiatry has certainly been his pioneering of modern doctrines of traumatic hysteria, which refers to neurological symptoms appearing after a trauma but not sufficiently explained by the trauma itself. ${ }^{79}$

The subject of traumatic neurosis had been explored by others before Charcot. In 1837, Benjamin Brodie had published on the subject of local nervous affections. ${ }^{80}$ Furthermore, Charcot was well aware of a significant paper, "Remarks on paralysis and other disorders of motion and sensation, dependent on idea", by Dr. J. Russell Reynolds at the University College Hospital in London, which appeared in the British Medical Journal in $1869 .{ }^{81}$ Also, with the expansion of railway systems and inevitable accidents, the concept of railway spine or railway brain emerged with all its legal implications. ${ }^{82,83}$ In fact, the greatest number of Charcot's descriptions of traumatic hysteria consisted of people involved in dramatic train accidents. ${ }^{84}$ Other causes mentioned by Charcot are minor and major work-related incidents, minor cuts, the death of a spouse, fright from combat experience and even thunderstorms.

Charcot had noticed since the 1870 s that even minor physical traumas could produce dramatic and very disabling bodily and psychological symptoms in some patients. In approximately 2 dozen accounts of traumatic hysteria, ${ }^{85}$ which he described more often in male patients, bodily symptoms were mainly of the neurological type, such as paralyses and anesthesias. Although Charcot noted depressive symptoms in many of his patients, he also described clusters of symptoms such as fatigue, nervousness, fearfulness, heart palpitations, insomnia and nightmares which remind us of certain aspects of what is now designated as PTSD.

Charcot conceptualized that hysteria in males was different from hysteria in females. Symptoms in men tended to be more chronic and less mobile than in women. He proposed that litigation could possibly explain this difference. However, at 
litigation could possibly explain this difference. However, at least some of these patients may have suffered closed head injury from their accidents, thus accounting for their intractability. ${ }^{70}$ In this respect, Charcot's claims were opposed by German neurologists such as Oppenheim ${ }^{86}$ who maintained that symptoms were produced by microscopic lesions to the central nervous system.

To account for such a spectrum of symptoms, Charcot eventually proposed a 2-fold etiology consisting of: i) an hereditary predisposition, and ii) the presence of a provocative agent. As emphasized well by Barrois, ${ }^{87}$ Charcot's insistence on the psychological impact of trauma distinguished him from other clinicians of his time. Although he tended to avoid theoretical discussions of how a psychological symptom could translate into a bodily symptom (this debate remains unresolved to this day), when he described his famous patient "Le Log", a 29year-old florist delivery man suffering from hysterical paralysis after being hit by a horse carriage, he fleetingly proposed "intense cerebral commotion" leading to an "obnubilation of consciousness" and a "dissociation of the ego" as a possible model. ${ }^{88}$ In this last stage, which Charcot compared to the somnambulistic trance produced through hypnosis, the idea of motor dysfunction, through unconscious auto-suggestion by the patient, became an idée fixe (fixed idea).

Charcot also described complicated cases of combined organic and hysterical manifestations. This is in line with modern observations in neurology that pathologies with cerebral involvement can predispose to conversion disorder. ${ }^{89-91}$ Charcot's further contributions to the understanding of traumatic hysteria include his description of an incubation period before the appearance of hysterical symptoms and what would now be called "post-traumatic amnesia". ${ }^{92}$ Indeed, it has recently been proposed that the difficulty in sorting out relevant memories as related to present sensory input seems linked to the norepinephrine system and various other neurohormones such as vasopressin and oxytocin. These systems could be implicated in the hypermnesias and amnesias associated with PTSD.$^{93}$ Charcot's description of an incubation period before the manifestation of symptoms could be related to these neurochemical systems.

As with hysteria, and as argued by Micale ${ }^{84}$ Charcot's contributions to "hystero-organic" causation tended towards an etiological integration of psychological and biological dimensions which antedates modern theories of the neuropsychology of trauma. In 1941, Kardiner ${ }^{94}$ coined the term physioneurosis to describe persistent symptoms of increased arousal following psychologically traumatic experiences. Kolb ${ }^{95}$ has proposed that trauma can induce permanent neuronal changes that modify learning and habituation performance. Others have commented on an exaggerated startle response, long been considered a cardinal consequence of trauma, which might also be a marker for susceptibility to PTSD. ${ }^{93}$ Many studies, some of which were done with Vietnam veterans, have suggested neuroendocrine abnormalities in PTSD ${ }^{96-99}$ Data derived from clinical populations have indicated hyperactivity of noradrenergic, opiate systems and the hypothalamic-pituitary-adrenal axis. ${ }^{66}$ Some studies have underlined a role of serotonergic systems. ${ }^{93,100}$ The implication of the limbic system (particularly the amygdala and the hippocampal system) in PTSD is now being examined. A study by Bremner et al. ${ }^{101}$ recently highlighted decreased right hippocampal volume in post-traumatic stress disorder.

Charcot's ideas on trauma and hysteria, through demonstra- tion of the psychological etiology of neuroses, laid some foundations for Sigmund Freud's psychoanalytic thought. It is wellknown that Freud studied under Charcot when the master's involvement with traumatic neuroses was at its peak. Under Charcot's influence, Freud went from being a neuro-anatomist to becoming a psychopathologist. ${ }^{49}$ In their introduction to Studies in Hysteria ${ }^{63}$ Freud and Breuer expressed gratitude to Charcot for "uncovering the psychical mechanism of hysteria". Although Charcot himself was well aware of the sexual overtones in la grande attaque, he himself had moved away from the still pervasive genital theories. This is in opposition to the emerging psychosexual theory of hysteria, at the time of his death. Indeed, Charcot's physiological concept of a bodily function being forgotten was in sharp contrast with Freud's repression of intra-psychic conflicts.

Freud's early works on aphasia, ${ }^{102}$ which he started elaborating shortly after his internship with Charcot, dealt with the difference between word representation and object association which eventually led to his concepts of the preconscious and the subconscious respectively. ${ }^{15}$ The purely psychogenic etiology of hysteria, as promulgated by the analytic model is, from the outset, inseparable from the notions of the unconscious, fantasy, conflict, repression, identification and secondary gain. ${ }^{79}$ The symbolic value carried by a symptom is seen in the context of primary and secondary gains. A cure is only possible through recollection and insight around repressed material. While watching the hallucinatory phase of la grande attaque, Freud had noticed that patients seemed to relive experiences important in the genesis of the disorder. As pointed out by Chertok, ${ }^{49}$ it is possible that by observing the tension between impulse and defence in the epileptoid phase of la grande attaque, Freud conceived some of his first ideas about repression. However, as pertains to traumatic experiences, Freud recognized that, after a severe shock, a "physical fixation" to the trauma persisted. ${ }^{103}$

Charcot's influence is no less important in the thought and works of his intern, Pierre Janet (1859-1947). Janet agreed with Charcot's concept of an hereditary weakness of the nervous system. He further proposed psychic weakness (which he called psychasthenia) as well as organic diseases of the nervous system, chronic illnesses and infectious diseases as predisposing factors to hysterical symptoms. Quite reminiscent of Charcot's comment on a "dissociation of the ego", Janet proposed dissociative processes, which maintained conversion symptoms outside of consciousness as being responsible for the production and persistence of symptoms. ${ }^{104}$ Concerning traumatic experiences, Janet also believed that, after a dissociation of particular events from consciousness, memories tended to be stored as images through flashbacks and nightmares and through bodily sensations such as anxiety and panic symptoms. ${ }^{105}$

Finally, as emphasized well by Barrois ${ }^{87}$ and Micale ${ }^{84}$ some of Charcot's ideas were reconsidered during the First and Second World Wars, when thousands of cases of traumatic hysteria were reported. Faced with this phenomenon, some clinicians studied Charcot to better understand how shell-shock or "war neurosis" was the consequence of extreme fear and fatigue, more than actual injury. ${ }^{106-109}$

\section{Conclusion}

The popular view of Charcot as a great neurologist discredited by his erring into the world of hysteria and hypnosis is an unfortunate one. In spite of his underestimation of the effects of 
unfortunate one. In spite of his underestimation of the effects of suggestion and demand characteristics, his treatment of hysteria was valid in many respects and resembles modern multi-modal approaches to conversion disorder. Furthermore, his psychological contributions through the notion of traumatic hysteria and his persistent allegiance to the organic etiology of diseases foreshadow more recent advances in the physiopathological impact of trauma. Although the concept of traumatic neurosis is not used as such in modern psychiatry, some of its facets are still valid. Shorter has accurately pointed out that "emotional shock runs like a red thread through psychiatric experience".?

Although the year 1993 represented the centenary of Charcot's death and recent contributions have greatly added to our understanding of his work, much still needs to be done to appreciate his creative genius and contributions to the interface between neurology and psychiatry. Although he remained a neurologist separate from the alienists of his time, his career and thought express in a very eloquent way some of the modern grounds for exchange between neurology and psychiatry. In this sense, his work has well survived Babinski's criticisms. More recently, the exponential development of functional neuroimaging, which is now increasingly applied to psychiatric disorders, constitutes an exquisite continuation of Charcot's anatomo-clinical approach.

\section{ACKNOWLEDGEMENTS}

I thank Germain Lavoie, Ph.D., Louis-H. Lafontaine Hospital, for his helpful suggestions and insights in reviewing this manuscript. Thanks are also extended to Dr. Deborrah Black, neurologist at the Louis-H. Lafontaine Hospital and Mr. Ovid Da Silva for their detailed reading of this manuscript.

This article was completed while the author was studying behavioral neurology under Dr. M.I. Botez, M.D., Ph.D., at the Hôtel-Dieu Hospital in Montreal, as part of a master's degree in sciences and a residency program in psychiatry.

\section{REFERENCES}

1. Cummings JL, Hegarty A. Neurology, psychiatry, and neuropsychiatry. Neurology 1994; 44: 209-213.

2. Revue Neurologique (Paris) 1994; 150: 485-542.

3. Gasser J. J.M. Charcot et le système nerveux: Etude de la motricité, du langage, de la mémoire, et de l'hystérie à la fin du XIXe siècle. Thèse de Doctorat. Ecole des Hautes Etudes en Sciences Sociales, Paris, 1990.

4. Goetz CG, Bonduelle M, Gelfand T. Charcot: Constructing Neurology. New York: Oxford University Press; 1995.

5. Gilman SL, King H, Porter R, Rousseau GS, Showalter E. Hysteria Beyond Freud. Berkeley: University of California Press; 1993.

6. Shorter E. From Paralysis to Fatigue: A History of Psychosomatic Illness in the Modern Era. New York: Free Press; 1992.

7. Shorter E. From the Mind into the Body: The Cultural Origins of Psychosomatic Symptoms. New York: Free Press; 1994.

8. Micale MS. Approaching Hysteria: Disease and Its Interpretations. Princeton: Princeton University Press; 1995.

9. Guillain G. J.M. Charcot (1825-1893): sa vie-son oeuvre. Paris: Masson; 1955.

10. Salomone G, Arnone R. Charcot and his drawings: images from "les leçons du mardi à la Salpêtrière 1887-1888". Ital J Neurol Sci 1994; 15: 203-211.

11. Goetz CG. Charcot: Scientific Bifrons. Rev Neurol (Paris) 1994; 150: $485-489$.

12. Charcot JM. Sur la claudication intermittente observée dans un cas d'oblitération complète de l'une des artères iliaques primitives. Gaz Med 1859; 282-286.

13. Charcot JM. Quelques documents concernant l'historique des gangrènes diabétiques. Gaz Hebd Med Chir 1861; V: 539.
14. Charcot JM. Leçons cliniques sur les maladies des vieillards et les maladies chroniques, recueillies et publiées par B. Ball. Paris: Asselin; 1866.

15. Gasser J. Charcot et les localisations cérébrales. De l'aphasie à l'amnésie. Rev Neurol (Paris) 1994; 150: 529-535.

16. Jeannerod M. La contribution de J.M. Charcot à l'étude des localisations motrices chez l'homme. Rev Neurol (Paris) 1994; 150: 536542.

17. Lellouch A. Charcot, Découvreur de Maladies. Rev Neurol (Paris) 1994; 150: 506-510.

18. Charcot JM, Vulpian EF. De la paralysie agitante. Gaz Hebd Med Chir 1862; VIII: 765-805.

19. Ballet G. Le domaine de la psychiatrie. La Presse Médicale 1911; May 10, 377-380.

20. Dejerine J. Clinique des maladies du système nerveux. Leçon inaugurale. La Presse Médicale 1911; April 1: 253-259.

21. Guinon G. A propos de deux travaux récents sur l'hystérie traumatique. La Presse Médicale 1888; Nov. 3: 316-319.

22. Charcot JM. Sur une nouvelle observation d'aphemie. Gaz Hebd Med Chir 1863; 10:473-474, 525.

23. Bouchard C. Aphasie sans lésion de la troisième circonvolution frontale gauche. Gaz Med Paris 1864; 489-490.

24. Janet P. J.M. Charcot: son oeuvre philosophique. Rev Philo 1895; 39: 569-604.

25. Lhermitte F, Signoret JL. L'aphasie de JM Charcot à Th. Alajouanine. Rev Neurol (Paris) 1982; 138: 893-919.

26. Ribot $T$. Les maladies de la mémoire. Paris: Baillière; 1881 .

27. Broca P. Atrophie cérébrale. Bull Soc Anatomique Paris 1963; 8: 379401.

28. Brais B. Jean Martin Charcot and aphasia: treading the line between experimental physiology and pathological anatomy. Brain Language 1993; 45: 511-530.

29. Wundt W. Grundzge der physiologischen Psychologie. Leipzig: Wilhelm Engelmann; 1873 .

30. Veith I. Hysteria: The History of a Disease. Chicago: University of Chicago Press; 1965.

31. Briquet P. Traité clinique et thérapeutique de l'hystérie. Paris: JB Baillière; 1859.

32. Négrier C. Recueil des faits pour servir à l'histoire des ovaires et des affections hystériques de la femme. Angers: Cosnier \& Lachèse; 1858.

33. Charcot JM. Leçons sur l'hystérie virile. Paris: La boîte de Pandore; 1984.

34. Micale M. Charcot and the idea of hysteria in the male: gender, mental science, and the medical diagnosis in late nineteenth-century France. Medical History 1990; 34: 363-411.

35. Widlocher D, Dantchev N. Charcot et l'hystérie. Rev Neurol (Paris) 1994; 150: 490-497.

36. Widlocher D. L'hystérie, cent ans après. Rev Neurol (Paris) 1982; 138: 1053-1060.

37. Charcot JM. Oeuvres complètes de JM Charcot: Leçons sur le système nerveux, recueillies et publiées par Babinski, Bernard, Féré, Guinon, Marie et Gilles de la Tourette. Paris: Bureaux du Progrès Médical, Lecrosnier et Babé; 1890, vol. 3: 330.

38. Charcot JM. Oeuvres complètes de JM Charcot: Leçons sur le système nerveux, recueillies et publiées par Babinski, Bernard, Féré, Guinon, Marie et Gilles de la Tourette. Paris: Bureaux du Progrès Médical, Lecrosnier et Babé; 1890, vol. 3: 340.

39. Orne MT. On the social psychology of the psychological experiment with particular reference to demand characteristics and their implications. Am Psychol 1962; 17: 776-783.

40. Van Dyck R, Hoogduin K. Hypnosis and conversion disorders. Am J Psychotherapy 1989; 43: 480-493.

41. Gowers W. Epilepsy and other chronic convulsive disorders. London: Churchill; 1881 .

42. Massey EW, McHenry LC. Hysteroepilepsy in the nineteenth century: Charcot and Gowers. Neurology 1986; 36: 65-67.

43. Babinski J. Démembrement de l'Hystérie Traditionnelle (Pithiatisme). Paris: Imprimerie de la Semaine Médicale; 1909.

44. Merskey $\mathbf{H}$. The Analysis of Hysteria. London: Baillière Tindall; 1979.

45. Marie-Cardine M, Collet B. L'hystérie. Confrontations Psychiatriques. Paris; 1985.

46. Critchley EMR, Cantor HE. Charcot's hysteria renaissant. Br Med J 1984; 289: 1785-1788.

47. Stevens $\mathrm{H}$. Is it organic or is it functional: is it hysteria or malingering? Psychiatr Clin North Am 1986; 9: 241-254. 
48. Goetz CG, Bonduelle M. Charcot as therapeutic interventionist and treating neurologist. Neurology 1995; 45: 2102-2106.

49. Chertok L. On the centenary of Charcot: hysteria, suggestibility and hypnosis. Br J Med Psychology 1984; 57: 111-120.

50. Charcot JM. Sur les divers états nerveux déterminés: l'hypnotisation chez les hystériques. Comptes rendus hebdomadaires des séances de l'Académie des Sciences 1882; 94: 402-405.

51. Kimball CP, Blindt K. Some thoughts on conversion. Psychosomatics 1982; 23: 647-649.

52. Ford CV, Folks DG. Conversion disorders: an overview. Psychosomatics 1985; 26: 371-383.

53. Hollander MH. Hysteria: the culture-bound syndromes. Papua New Guinea Med J 1976; 19: 24-29.

54. Mechanic D. The concept of illness behavior. J Chron Dis 1962; 15: 189-194.

55. Charcot JM. Oeuvres complètes de JM Charcot: Leçons sur le système nerveux, recueillies et publiées par Babinski, Bernard, Féré, Guinon, Marie et Gilles de la Tourette. Paris: Bureaux du Progrès Médical, Lecrosnier et Babé; 1890, vol. 3: 239.

56. Ron M. Somatization in neurological practice. J Neurol Neurosurg Psychiatry 1994; 57: 1161-1164.

57. Bass C, Benjamin S. The management of chronic somatization. Br J Psychiatry 1993; 162: 472-480.

58. Keane JR. Hysterical gait disorders: 60 cases. Neurology 1989; 39: 586-589.

59. Hurwitz TA. Narcosuggestion in chronic conversion symptoms using combined intravenous amobarbital and methylphenidate. Can J Psychiatry $1988 ; 33: 147-152$.

60. Maisami M, Freeman JM. Conversion reactions in children as body language: a combined child psychiatry/neurology team approach to the management of functional neurologic disorders in children. Pediatrics 1987; 80: 46-52.

61. Mai FM. "Hysteria" in clinical neurology. Can J Neurol Sci 1995; 22: $101-110$

62. Maurice-Williams RS, Marsh H. Simulated paraplegia: an occasional problem for the neurosurgeon. J Neurol Neurosurg Psychiatry 1985; 48: 826-831.

63. Breuer J, Freud S. Studies in Hysteria. New York: Nervous and Mental Diseases Publishing Company; 1956.

64. American Psychiatric Association. Diagnostic and Statistical Manual of Mental Disorders (Rev 4th ed). Washington, DC: American Psychiatric Association; 1994.

65. Shorter $\mathrm{E}$. The borderland between neurology and history: conversion reactions. Neurologic Clinics 1995; 13(2): 229-239.

66. Kaplan HI, Saddock BJ. Synopsis of Psychiatry. Baltimore, MD: Williams \& Wilkins; 1991, 1994

67. Lempert T, Dietrich M, Huppert D, Brandt T. Psychogenic disorders in neurology: frequency and clinical spectrum. Acta Neurol Scand 1990; 82: 335-340.

68. Mardsen CD. Hysteria, a neurologist's view. Psychol Med 1986; 16: 277-288.

69. Brisset C. Hystérie et psychosomatique: les rapports de la structure et de l'histoire. Evol Psychiatr 1970; 377-404.

70. Thorton EM. Freud and Cocaine: The Freudian Fallacy. London: Blond \& Briggs; 1983.

71. Kaplan HI, Saddock BJ. Comprehensive Textbook of Psychiatry/VI. Baltimore, MD: Williams \& Wilkins; 1995.

72. Tomasson K, Kent D, Coryel IW. Somatization and conversion disorders: comorbidity and demographics at presentation. Acta Psychiatr Scand 1991; 84: 288-293.

73. Folks DG, Ford CV, Regan W. Conversion symptoms in a general hospital. Psychosomatics 1984; 25: 285-295.

74. Ziegler FJ, Imboden JB, Meyer E. Contemporary conversion reactions. Am J Psychiatry 1960; 116: 901-910.

75. Galin D, Diamond R, Graff D. Lateralization of conversion symptoms: more frequent on the left. Am J Psychiatry 1977; 134: 578580.

76. Ludwig AM. Hysteria: a neurobiologic theory. Arch Gen Psychiatry 1972; $27: 771-777$.

77. Whitlock F. The aetiology of hysteria. Acta Psychiatr Scand 1967; 43: 144-162.

78. Flor-Henry P, Frown-Augh D, Tepper M, et al. A neuropsychological study of the stable syndrome of hysteria. Biol Psychiatry 1981;16: 601-626.
79. Laplanche J, Pontalis JB. Vocabulaire de la Psychanalyse (1ière ed.). Paris: Presses Universitaires de France; 1967.

80. Brodie B. Lectures Illustrative of Certain Local Nervous Affections. London: Longman, Rees, Orme, Brown, Green \& Longman; 1837.

81. Reynolds JR. Remarks on paralysis and other disorders of motion and sensation, dependent on idea. Br Med J 1869; ii: 483-485. Discussion, 378-379.

82. Erichsen JE. On Railway and Other Injuries of the Nervous System. London: Walton \& Moberly; 1866.

83. Putnam J. Recent investigations into the pathology of so-called concussion of the spine. Boston Med Surg J 1883; 109: 217-220.

84. Micale M. Charcot and les névroses traumatiques: historical and scientific reflections. Rev Neurol (Paris) 1994; 150: 498-505.

85. Charcot JM. Leçons sur l'hystérie virile. Paris: Le Syncomore, 1984.

86. Oppenheim H. Die traumatischen Neurosen. Berlin: August Hirschwald; 1889.

87. Barrois C. Les névroses traumatiques: le psychothérapeute face aux détresses des chocs psychiques. Paris: Dumod; 1988.

88. Charcot JM. Oeuvres complètes de JM Charcot: leçons sur le système nerveux, recueillies et publiées par Babinski, Bernard, Féré, Guinon, Marie et Gilles de la Tourette. Paris: Bureaux du Progrès Médical, Lecrosnier et Babé; 1890, vol. 3: 451.

89. Lloyd GG. Acute behaviour disturbances. J Neurol Neurosurg Psychiatry 1993; 56: 1149-1156.

90. Drake ME. Conversion hysteria and dominant hemisphere lesions. Psychosomatics 1993; 34: 524-530.

91. Eames P. Hysteria following brain injury. J Neurol Neurosurg Psychiatry 1992; 55: 1046-1053.

92. Charcot JM. Oeuvres complètes de JM Charcot: Leçons sur le système nerveux, recueillies et publiées par Babinski, Bernard, Féré, Guinon, Marie et Gilles de la Tourette. Paris; Bureaux du Progrès Médical, Lecrosnier et Babé; 1890 vol. 3: 456.

93. van der Kolk BA, McFarlane AC, Weisaeth L. Traumatic Stress: The Effects of Overwhelming Experience on Mind, Body, and Society. New York: The Guilford Press; 1996.

94. Kardiner A. The traumatic neuroses of war. In: Psychosomatic Medicine Monograph (I-II). Washington, DC: National Research Council; 1941.

95. Kolb LC. Neurophysiological hypothesis explaining posttraumatic stress disorder. Am J Psychiatry 1987; 144: 989-995.

96. Southwick SM, Krystal JH, Morgan A, et al. Abnormal noradrenergic function in post-traumatic stress disorder. Arch Gen Psychiatry 1993; 50: 266-274.

97. Pitman RK, Orr SP. Twenty-four hour urinary cortisol and catecholamine excretion in combat-related post-traumatic stress disorder. Biol Psychiatry 1990; 27: 245-247.

98. Yehuda R, Southwick SM, Mason JW, Giller EL. Interactions of the hypothalamic-pituitary-adrenal axis and the catecholaminergic system in posttraumatic stress disorder. In: Giller EL, ed. Biological Assessment and Treatment of PTSD. Washington, DC: American Psychiatric Press; 1990.

99. Mason J, Giller EL, Kosten TR. Elevated norepinephrine/cortisol ratio in PTSD. J Ment Nerv Dis 1988; 176: 498-502.

100. van der Kolk BA, van der Hart O. The intrusive past: the flexibility of memory and the engraving of trauma. Am Imago 1991; 48: 425-454.

101. Bremner JD, Randall P, Scott TM, et al. MRI-based measurement of hippocampal volume in patients with combat-related posttraumatic stress disorder. Am J Psychiatry 1995; 152: 973-981.

102. Freud S. Zur Auffassung der Aphasien, eine kritische Studie. Leipzig and Wien: Deuticke; 1891.

103. Freud S. Introduction to Psychoanalysis and the War Neuroses. Strachey J, trans/ed. Standard ed. London: Hogarth Press; 1919/1954. 17: 207-210.

104. Janet P. The Major Symptoms of Hysteria. New York: MacMillan; 1907.

105. Janet P. L'automatisme psychologique. Paris: Alcan; 1889.

106. Grinker RR. Treatment of war neuroses. JAMA 1944; 126: 142-145.

107. Wilde JF. Narco-analysis in the treatment of war neurosis. Br Med J $1942 ; 2: 4-7$

108. Eder MD. War-Shock. London: W. Heineman; 1917.

109. MacCurdy JT. War Neuroses. Cambridge; 1918. 